\title{
Infection risk among adults with down syndrome: a two group series of 101 patients in a tertiary center
}

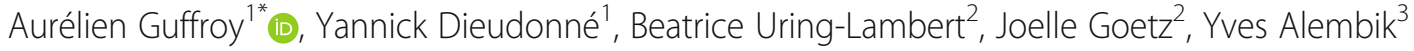 \\ and Anne-Sophie Korganow ${ }^{1}$
}

\begin{abstract}
Background: Down syndrome (DS) is the most common form of viable chromosomal abnormality. DS is associated with recurrent infections, auto-immunity and malignancies in children. Little is known about immunity and infections in DS at adulthood.

Methods: We studied two separate group of adults ( $>18$ years old) with DS in a single referral tertiary center (Strasbourg University Hospital). The first group included 37 ambulatory DS patients between November 2014 and May 2017. We analyzed exhaustive serological and immunobiological parameters, at one point, together with the prevalence of infections, autoimmune manifestations and malignancies. The second group included 64 hospitalized patients (138 stays) in the same center, between January 2005 and December 2016.

Results: One hundred and one adult patients with DS were included. Unlike children and despite a global lymphopenia, adults with DS underwent few infections in our ambulatory group. They did not experience any malignancy and, apart from hypothyroidism, they presented only occasional autoimmune manifestations. Hospitalized DS patients were older than ambulatory ones (median age 47 years (18-73) vs. 27 (18-52), $p<0.0001$ ) and admitted mostly for infections (76.8\%). Infections were associated with epilepsy and dementia (OR 6.5 (2.2-19), $p=0.001 ; p=0.0006$ in multivariate analysis) and higher mortality (OR 7.4 (1.4-37), $p=0.01$ ).

Conclusion: Despite persistent immunobiological abnormalities at adulthood, young ambulatory adults with DS remain healthy with a low rate of infections. Infections are associated with neurological degeneration and increase the mortality arguing for a dedicated support of older DS patients.
\end{abstract}

Trial registration: ClinicalTrials.gov: NCT01663675 (August 13, 2012). Hospital Clinical Research Program (PHRC): number 2012-A00466-37 (Dr Y. Alembik).

Keywords: Down syndrome, Immunodeficiency, Infectious risk, Neurological impairment, Adult

\section{Introduction}

Down syndrome (DS) caused by trisomy 21 is the most common form of viable chromosome abnormality in children and the prevalence of DS continues to increase with life expectancy [1]. Survival of patients with DS improved drastically in the past few decades, with the

\footnotetext{
* Correspondence: aurelien.guffroy@chru-strasbourg.fr; aurelienguffroy@hotmail.com

${ }^{1}$ Department of Clinical Immunology and Internal Medicine, National Reference Center for Autoimmune Diseases, Hôpitaux Universitaires de Strasbourg, 1, place de l'Hôpital, 67091 Strasbourg, France

Full list of author information is available at the end of the article
}

detection and the early surgical care of congenital heart malformations (atrioventricular septal, ventricular septal, and atrial septal defects or persistent patent ductus arteriosus) [2]. The median age at death is now mid-50's compared to 10 years of age in the 1970's [3, 4]. Children with DS have a high incidence of infections of the respiratory tracts [5]. Over the last 3 decades, these infections have been linked to both innate and adaptive immunological abnormalities. Studies describing the immune system of infants with DS report the reduction and an altered distribution of $\mathrm{T}$ and $\mathrm{B}$ cell populations $[6,7]$ coupled to a poor response to vaccines [8-11].

(c) The Author(s). 2019 Open Access This article is distributed under the terms of the Creative Commons Attribution 4.0 International License (http://creativecommons.org/licenses/by/4.0/), which permits unrestricted use, distribution, and reproduction in any medium, provided you give appropriate credit to the original author(s) and the source, provide a link to the Creative Commons license, and indicate if changes were made. The Creative Commons Public Domain Dedication waiver (http://creativecommons.org/publicdomain/zero/1.0/) applies to the data made available in this article, unless otherwise stated. 
Thus, it has been suggested that children with DS share similarities with patients affected with primary immunodeficiency (PID) and some PIDs classifications include DS [12, 13]. In contrast with pediatric literature, there is a lack of information about infections and immune parameters in adults with DS. Herein we report the features of 101 adults with DS.

\section{Methods}

Following approvement of our Institutional Boards, we studied two separate groups of adults ( $>18$ years old) with DS in Strasbourg University Hospital (Fig. 1). The first group included ambulatory DS patients (Department of Medical Genetic) between 2014 and 2017. We analyzed at one point serological and immunobiological parameters, together with the retrospective prevalence of infections, autoimmune manifestations and malignancies. The second group included hospitalized patients between 2005 and 2016 with associated DS ICD codes or key words "Down syndrome" or "Trisomy 21" in medical letters with the mean of systematic research by the medical information department of the hospital. We excluded patients hospitalized for scheduled exams.

We used Fisher's exact test to compare qualitative variables and Student test for quantitative variables in univariate analysis. Mann-Whitney test was used to compare non-normally distributed variables. Multivariate analyzes were done for a $p$-value $<0.10$ in univariate analysis using ridge logistic regression. Statistical significance was defined by $p<0.05$ in 2 -tailed tests.

\section{Results}

Thirty-seven patients came to the medical genetic consultation for DS (Table 1). Median age was 27 years (18-52). None was in institutional care. Frequent infections were reported during childhood for 20 DS patients (54\%), the leading manifestations involving respiratory tract $(49 \%)$ and ENT $(16 \%)$. Only one patient was identified with recurrent infectious events after the age of 18 . Total lymphocyte counts of DS patients were low when compared to standards (1480 cells $/ \mu \mathrm{L}$ vs. 2170 cells $/ \mu \mathrm{L}, p=0.004)$ concerning especially naïve and memory $B$ cell subsets as described in DS children. 15 patients presented with hypergammaglobulinemia ( $\operatorname{IgG}>15 \mathrm{~g} / \mathrm{L}$ ) and increased IgG1 and IgG3 levels. Serological status following vaccination for DPT (Diphteria, Polio and Tetanus), Streptococcus pneumoniae and Haemophilus influenzae showed protective titers in most cases.

During an 11 year period (2005-2016), 64 DS patients were hospitalized at Strasbourg University Hospital, mainly in Internal Medicine, Infectious diseases, Pneumology and Intensive Care Units corresponding to 138 stays (a total of 190,740 stays were recorded in the same departments during this period), (Table 2). Median age was 47 years (18-73), older than ambulatory ones $(p<0.0001)$. Thirty-seven patients $(58 \%)$ were in institutional care. The outstanding causes for hospitalization among DS patients were infections $(n$ $=106 / 138)$, mostly aspiration pneumonia $(n=91 / 138)$. When available, lymphocyte counts and Ig levels were

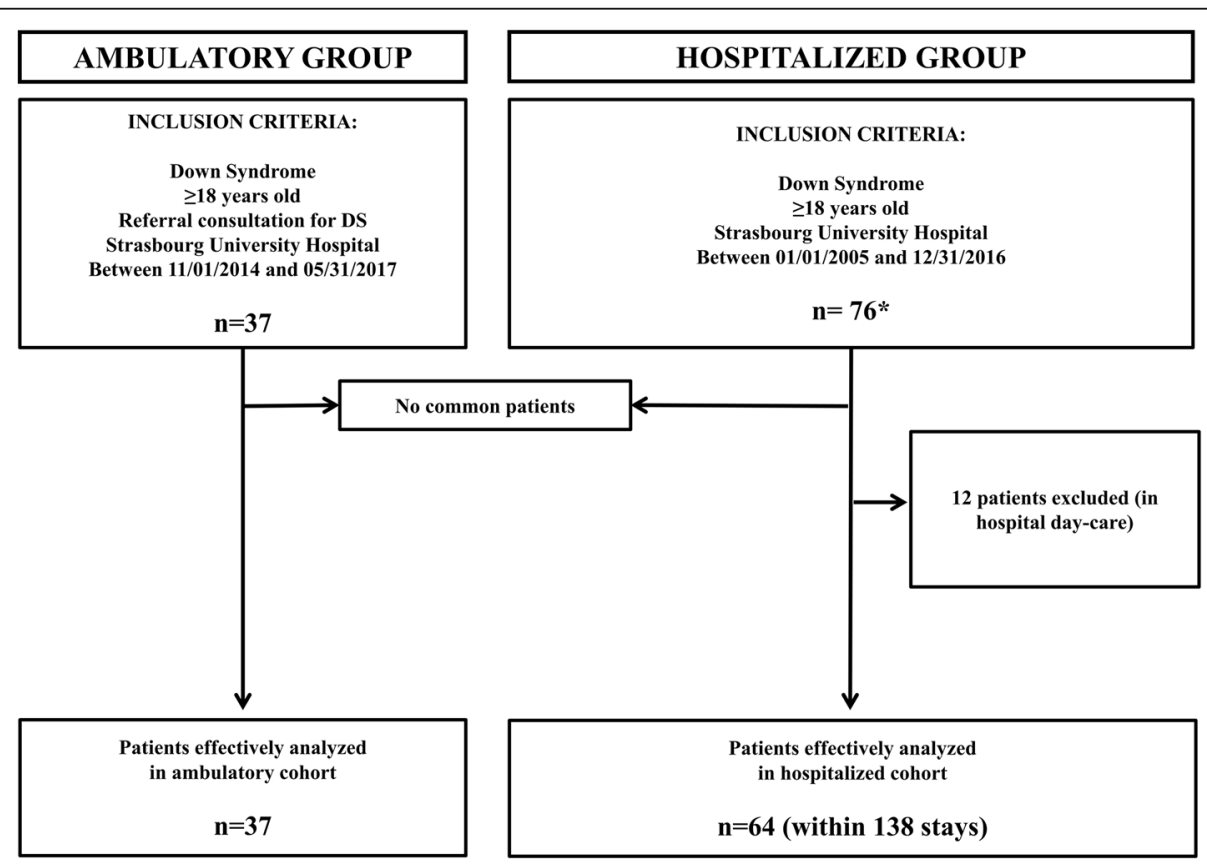

Fig. 1 Flow diagram of patients. *Within 190,740 stays - **Patients were excluded for insufficient data when the cause of hospitalization was not mentioned, or when clinical and biological data were unavailable 
Table 1 Ambulatory DS patients

Demographics and clinical characteristics of ambulatory DS patients

Age at inclusion (years)

Sex ratio (F/M)

Institutional living (n, \%)

Recurrent infections within childhood

Before 5 years old

From 6 to 18 years old

Recurrent respiratory tract infections at adulthood ${ }^{a}$

Hypothyroidism

Epilepsy

Dementia

Cardiac congenital disease

Urogenital malformation

Gastrointestinal malformation

Type 1 diabetes

Celiac disease

Hematological malignancy

Biological features of ambulatory DS patients

Neutrophils (cells/ $\mu \mathrm{L}$ )

Lymphocytes (cells/ $\mathrm{LL})$

$T$ cells (cells $/ \mu \mathrm{L}$ )

CD4+ T cells (cells/ $\mu \mathrm{L})$

CD8+ T cells (cells/ $\mu \mathrm{L})$

Naïve CD45RA+ (\% of T-cells)

Memory CD45RO+ (\% of T-cells)

Regulatory T cells CD3 + CD25 + FoxP3+ (\% of CD4+)

NK cells CD3-CD56+ (cells/ $\mu \mathrm{L})$

CD19+ B cells (cells/ $\mu \mathrm{L})$

Naive CD27- $\lg \mathrm{D}+($ cells $/ \mu \mathrm{L})$

Transitional CD24 + CD38+ (cells/ $\mu \mathrm{L})$

Switched memory CD27 + lgD- (cells/ $\mu \mathrm{L})$

Marginal zone CD27 + lgD+ (cells/mL)

Plasmablast CD27-CD38+ (cells/ML)

CD21lowCD38low (cells/uL)

$\lg G(g / L)$

$\lg G 1(g / L)$

$\lg G 2(g / L)$

$\operatorname{lgG3}(\mathrm{g} / \mathrm{L})$

$\operatorname{lgG} 4(\mathrm{~g} / \mathrm{L})$

$\lg \mathrm{M}(\mathrm{g} / \mathrm{L})$

$\lg A(g / L)$

Anti-nuclear antibodies (ANAs) (n, \%)

Anti-ds DNA antibodies (anti-ds DNA Abs) (n, \%)

Anti-thyroperoxidase antibodies ${ }^{\mathrm{b}}$ (anti-TPO Abs) (n, \%)

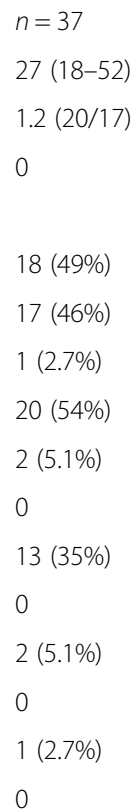

0

2 (5.4\%) 
Table 1 Ambulatory DS patients (Continued)

\begin{tabular}{lc}
\hline Serological status (protective titer $^{\mathrm{C}}$ ) & $\mathrm{n}=37$ \\
Tetanus & $36(97 \%)$ \\
Polio & $33(89 \%)$ \\
Diphteria & $19(51 \%)$ \\
Haemophilus influenzae type b & 30 (81\%) \\
Streptococcus pneumoniae & 34 (92\%) \\
\hline
\end{tabular}

${ }^{\mathrm{a}}>2$ pneumoniae or bronchitis with need of antibiotherapy (after 18 years old) ${ }^{\mathrm{b}}$ Anti-TPO antibodies were searched for 26 patients ${ }^{\mathrm{c}} 37$ patients were inoculated against diphteria tetanus and poliomyelitis (DTP vaccine), 35 (97\%) against BCG (Bacillus of Calmette and Guerin), 27 (73\%) against Bordetella pertussis, 8 (22\%) against Haemophilus influenza type b and $2(5 \%)$ against Streptococcus pneumoniae. Protective titers were defined using manufacturers' values

comparable to those of the ambulatory patients. Infections were associated with epilepsy and dementia (OR 6.5 (2.2-19), $p=0.001 ; p=0.0006$ in multivariate analysis) and higher mortality (OR $7.4(1.4-37), p=0.01)$. We found a median of second infectious event at 6.9 months in the group with neurological diseases vs. more than 120 months in the group without neurological diseases ( $p$ $=0.002$, Fig. 2). Furthermore, the annual rate of infection dramatically increased with age in hospitalized group with a 5 fold increase of incidental infections after 50 years (Additional file 1: Figure S1).

\section{Discussion}

In DS children, epidemiological [1, 14-18] and pathophysiological $[6,19-22]$ evidences argue for a higher risk of infectious events, hematological malignancies and autoimmunity. Our work correlates for the first time detailed immunological findings and infectious events in adult patients with DS. Despite persistent T and B cell alterations, young ambulatory adults with DS have a low risk of infections, suggesting offsetting mechanisms in adulthood. However, infections, mostly bacterial aspiration pneumonia, remain the first cause of hospitalization. The major factor associated with infectious complications and premature death is the occurrence of neurological diseases such as seizures and dementia [23]. Seizures are frequent in adults with Down's syndrome with about 10 times increased incidence as compared to general population. Seizures are associated with aging and cognitive impairment in DS [24]. Development of dementia in DS syndrome dramatically increases after age of 40 and is one of the main

Table 2 Hospitalized DS patients $(n=64)$ : comparison between DS patients with or without recurrent infections

\begin{tabular}{|c|c|c|c|c|c|}
\hline & $\begin{array}{l}\text { Infections }^{a} \\
(n=31)\end{array}$ & $\begin{array}{l}\text { No Infections } \\
(n=33)\end{array}$ & $\begin{array}{l}\text { OR } \\
/ H R\end{array}$ & $\begin{array}{l}\text { Univariate } \\
p^{*}\end{array}$ & $\begin{array}{l}\text { Multivariate } \\
p^{* *}\end{array}$ \\
\hline Age (years) & $51(19-73)$ & $45(18-65)$ & / & 0.01 & 0.12 \\
\hline Sex ratio (F/M) & $0.35(8 / 23)$ & $0.8(15 / 18)$ & $0.41(0.14-1.2)$ & 0.12 & 0.16 \\
\hline Institutional living (n, \%) & $21(68)$ & $16(48)$ & $2.2(0.8-6.1)$ & 0.12 & 0.89 \\
\hline Hypothyroidism (n, \%) & $14(45)$ & $13(40)$ & $1.2(0.46-3.4)$ & 0.8 & / \\
\hline Cardiac congenital disease (n, \%) & $5(16)$ & $5(15)$ & $1.1(0.27-4.1)$ & 1 & 0.06 \\
\hline Gastrointestinal malformation (n, \%) & $2(6.4)$ & $2(6)$ & $1.1(0.14-8.0)$ & 1 & / \\
\hline Neurological disease ${ }^{b}(n, \%)$ & $22(71)$ & $9(27)$ & $6.5(2.2-19)$ & 0.001 & 0.0006 \\
\hline Epilepsy ( $n, \%)$ & $16(52)$ & $7(21)$ & $3.9(1.3-12)$ & 0.02 & / \\
\hline Dementia (n, \%) & $13(42)$ & $3(9)$ & $7.2(1.8-29)$ & 0.003 & / \\
\hline Hematological malignancy (n, \%) & 0 & $1(3)$ & $0.34(0.1-9)$ & 1 & / \\
\hline Lymphocytes rate $(/ \mu \mathrm{L})$ & $1340(650-2580)$ & $1575(558-3710)$ & / & 0.09 & 0.13 \\
\hline Lymphocytes < 1000/mm3 (n, \%) & $9(29)$ & $5(15)$ & $2.3(0.67-7.8)$ & 0.23 & / \\
\hline Immunoglobulin rate (g/L) & $12(7-23)$ & $16(9-18)$ & / & 0.22 & / \\
\hline Mortality (n, \%) & $10(32)$ & $2(6)$ & $7.4(1.4-37)$ & 0.01 & / \\
\hline
\end{tabular}

${ }^{a}$ Total number of infectious events: 106 (/138 stays); intensive care unit admission 11/106; Need of pressor amines 7/106, Acute lung injury syndrome 3/18; Pneumonia 96/106 (91\%). The other reasons were seizures $(n=8)$, heart failure $(n=5)$, occlusive syndrome $(n=5)$, arterial cardiovascular event $(n=5)$, syncope $(n$ $=4)$, acute renal disease $(n=2)$, pancreatitis, venous thrombosis, deep weight loss ( $n=1$ each)

${ }^{\mathrm{b}}$ Neurological disease was defined as epilepsy or dementia

*Difference between infections and no infections groups using Fischer's test for categorical variables and Mann-Whitney test for quantitative variables

**Using multiple logistic regression. OR: Odd Ratio - HR: Hazard Ratio

Statistically significant results are marked in boldface 


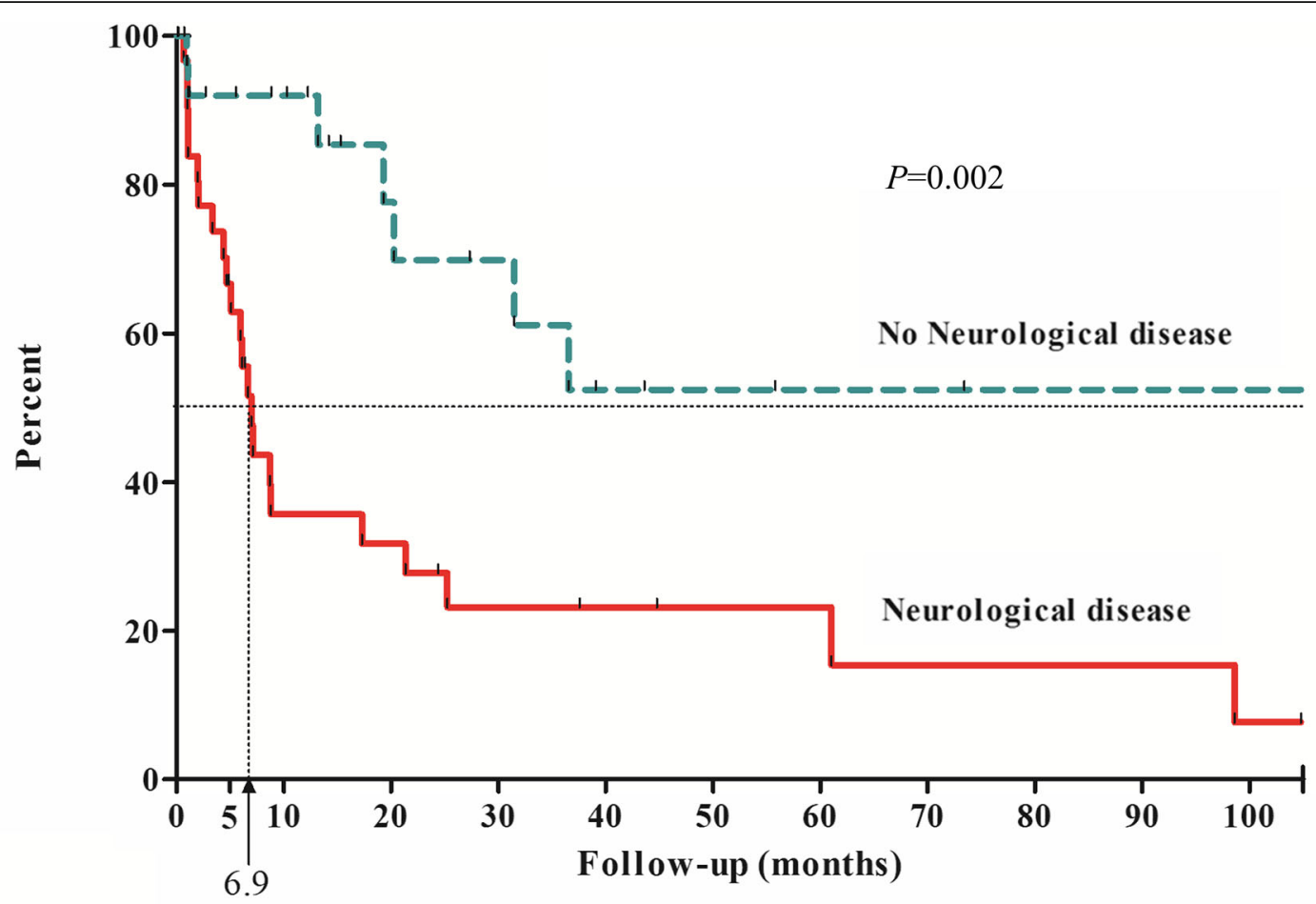

$\mathrm{N}^{\circ}$ at risk

Neurological disease

Fig. 2 Time to second infectious event within the DS hospitalised group. The median duration of second infectious event-free survival was 6.9 months within the group with neurological disease, as compared with a median over the last follow up (105 months) in the group with no neurological disease. Hazard ratio $0.05(p=0.002)$

cause of institutionalization and hospitalization [4, 24]. Considering pediatric studies and our work, infections in DS occur early in life up and in the second adulthood period -after 50 years-old- especially when neurological comorbidities are associated. Indeed, neurological impairment marks a turning point in the infectious complications of adults patients with DS and this should be kept in mind by physicians.

\section{Additional file}

Additional file 1: Figure S1. Annual rate of infection by 5-years range within the hospitalized DS patients. (TIF $4139 \mathrm{~kb}$ )

\section{Abbreviations}

DPT: Diphtheria, Polio and Tetanus; DS: Down Syndrome; ENT: Ear, Nose and Throat; ICD-10: International Classification of Diseases (version 10); mAb: monoclonal Antibody; PID: Primary Immune Deficiency

\section{Acknowledgments}

Additional contributions:

PHRC T21 study group: Emmanuel Andres, MD, PhD, Xavier Argemi, MD, PhD, Frédéric Blanc, MD, PhD, Isabelle Brun, MD, Salima El Chehadeh, MD, Jean-Luc Davideau, MD, Jean-Louis Dietemann, MD, PhD, Hélène Dollfus,
MD, PhD, Elise Gazzano, MD, Bernard Goichot, MD, PhD, Julie Helms, MD, Jean-Michel Hiebel, MD, Georges Kaltenbach, MD, PhD, Anne Koenig, MD, PhD, Marie-Cécile Manière, PhD, Yaumara Perdomo, MD, Hélène PetitEisenmann, MD, PhD, Alain Pradignac, MD, PhD, Anne-Elisabeth Quoix, MD, PhD, Philippe Sauder MD PhD, Elise Schaefer, MD, Francis Schneider, MD, PhD, Dana Timbolschi, MD, Jean-Christophe Weber, MD (Strasbourg University Hospital) contributed clinical and administrative collaborative efforts. Insightful comments on the manuscript: Laurent Arnaud MD, PhD (Strasbourg University Hospital) and Hans Hartmut Peter MD, PhD (Universitätsklinikum Freiburg). No compensation was received.

We thank the patients, families and staff for their time and dedication.

\section{Funding}

Fundings/grants:

Dr. Yves Alembik (grant from the French Ministry of Health PHRC 2012A00466-37),

Pr. Anne-Sophie Korganow (grant from EU-funded (ERDF) project INTERREG V "RARENET").

\section{Availability of data and materials}

All data generated or analyzed during this study are included in this published article [and its additional files].

\section{Authors' contributions}

AG (corresponding author) had full access to all of the data in the study and takes responsibility for the integrity of the data and the accuracy of the data analysis. Study concept and design: AG, YD, YA, ASK, Acquisition, analysis, or interpretation of data: all authors, Drafting of the manuscript: AG, YD, ASK, Critical revision of the manuscript for important intellectual contents: all 
authors, Statistical analysis: AG, YD, ASK, Administrative, technical, or material supports: all authors, Study supervision: AG, YA, ASK. All authors read and approved the final manuscript.

Ethics approval and consent to participate Ambulatory patients involved in PHRC T21 "Trisomy 21 in Adulthood": (Dr Alembik Yves): All subjects were recruited under a protocol approved by ethical board CPP-Est IV N¹2/47 (research ethical board of Strasbourg University Hospital) including a written informed consent.

Retrospective hospitalized patients: An approval statement from the local ethical committee has been obtained (ethical committee of the Faculties of Medicine and Dentistry of Strasbourg N²018-8).

\section{Consent for publication}

Not applicable.

\section{Competing interests}

The authors declare that they have no competing interests.

\section{Publisher's Note}

Springer Nature remains neutral with regard to jurisdictional claims in published maps and institutional affiliations.

\section{Author details}

'Department of Clinical Immunology and Internal Medicine, National Reference Center for Autoimmune Diseases, Hôpitaux Universitaires de Strasbourg, 1, place de l'Hôpital, 67091 Strasbourg, France. ²Department of Immunobiology, Hôpitaux Universitaires de Strasbourg, 67091 Strasbourg, France. ${ }^{3}$ Department of Clinical Genetic, Hôpitaux Universitaires de Strasbourg, 67091 Strasbourg, France.

Received: 1 March 2018 Accepted: 28 December 2018 Published online: 11 January 2019

\section{References}

1. Irving C, Basu A, Richmond S, Burn J, Wren C. Twenty-year trends in prevalence and survival of Down syndrome. Eur J Hum Genet. 2008;16: $1336-40$.

2. Jensen KM, Bulova PD. Managing the care of adults with Down's syndrome. BMJ. 2014;349:95596

3. Genes and human disease. In: Who World Health Organization. Available from: http://www.who.int/genomics/public/geneticdiseases/en Accessed 18 Dec 2018.

4. Englund A, Jonsson B, Zander CS, Gustafsson J, Annerén G. Changes in mortality and causes of death in the Swedish Down syndrome population. Am J Med Genet A. 2013;161:642-9.

5. Ram G, Chinen J. Infections and immunodeficiency in Down syndrome: immunodeficiency in Down syndrome. Clin Exp Immunol. 2011:164:9-16.

6. Verstegen RHJ, Driessen GJ, Bartol SJW, van Noesel CJM, Boon L, van der Burg $M$, et al. Defective B-cell memory in patients with Down syndrome. J Allergy Clin Immunol. 2014;134:1346-53.

7. Schoch J, Rohrer TR, Kaestner M, Abdul-Khaliq H, Gortner L, Sester U, et al. Quantitative, phenotypical, and functional characterization of cellular immunity in children and adolescents with Down syndrome. J Infect Dis. 2017:215:1619-28.

8. Kusters M a A, Manders NCC, de Jong B a W, van Hout RWNM, Rijkers GT, de Vries E. Functionality of the pneumococcal antibody response in Down syndrome subjects. Vaccine. 2013;31:6261-5.

9. Kusters MA, Bok VLA, Bolz WEA, Huijskens EGW, Peeters MF, de Vries E. Influenza a/H1N1 vaccination response is inadequate in Down syndrome children when the latest cut-off values are used. Pediatr Infect Dis J. 2012; 31:1284-5.

10. Kusters MA. Jol-Van Der Zijde ECM, Gijsbers RHJM, de Vries E. Decreased response after conjugated meningococcal serogroup $C$ vaccination in children with Down syndrome Pediatr Infect Dis J. 2011;30:818-9.

11. Kusters MA, Jol-van der Zijde CM, van Tol MJ, Bolz WE, Bok LA, Visser M, et al. Impaired avidity maturation after tetanus toxoid booster in children with Down syndrome. Pediatr Infect Dis J. 2011;30:357-9.

12. Ming JE, Stiehm ER, Graham JM. Syndromic immunodeficiencies: genetic syndromes associated with immune abnormalities. Crit Rev Clin Lab Sci. 2003;40:587-642.
13. Cuadrado E, Barrena MJ. Immune dysfunction in Down's syndrome: primary immune deficiency or early senescence of the immune system? Clin Immunol Immunopathol. 1996;78:209-14.

14. Bloemers BLP, Broers CJM, Bont L, Weijerman ME, Gemke RJBJ, van Furth AM. Increased risk of respiratory tract infections in children with Down syndrome: the consequence of an altered immune system. Microbes Infect Inst Pasteur. 2010;12:799-808.

15. Hasle $\mathrm{H}$, Clemmensen $\mathrm{H}$, Mikkelsen M. Risks of leukaemia and solid tumours in individuals with Down's syndrome. Lancet Lond Engl. 2000;355:165-9.

16. Roizen NJ, Patterson D. Down's syndrome. Lancet. 2003;361:1281-9.

17. Yang Q, Rasmussen SA, Friedman JM. Mortality associated with Down's syndrome in the USA from 1983 to 1997: a population-based study. Lancet Lond Engl. 2002;359:1019-25.

18. Linabery AM, Li W, Roesler MA, Spector LG, Gamis AS, Olshan AF, et al. Immune-related conditions and acute leukemia in children with Down syndrome: a Children's oncology group report. Cancer Epidemiol Biomark Prev Publ Am Assoc Cancer Res Cosponsored Am Soc Prev Oncol. 2015;24: 454-8.

19. Bloemers BLP, van Bleek GM, Kimpen JLL, Bont L. Distinct abnormalities in the innate immune system of children with Down syndrome. J Pediatr. 2010:804-9.

20. Bloemers BLP, Bont $L$, de Weger RA, Otto SA, Borghans JA, Tesselaar K. Decreased Thymic output accounts for decreased naive T cell numbers in children with Down syndrome. J Immunol. 2011;186:4500-7.

21. Carsetti R, Valentini D, Marcellini V, Scarsella M, Marasco E, Giustini F, et al. Reduced numbers of switched memory B cells with high terminal differentiation potential in Down syndrome: clinical immunology. Eur J Immunol. 2015:45:903-14.

22. Verstegen RHJ, Kusters MAA, Gemen EFA, DE Vries E. Down syndrome B lymphocyte subpopulations, intrinsic defect or decreased T-lymphocyte help. Pediatr Res. 2010;67:563-9.

23. Lott IT, Dierssen M. Cognitive deficits and associated neurological complications in individuals with Down's syndrome. Lancet Neurol. 2010;9: 623-33.

24. Menéndez M. Down syndrome, Alzheimer's disease and seizures. Brain and Development. 2005;27:246-52.

\section{Ready to submit your research? Choose BMC and benefit from:}

- fast, convenient online submission

- thorough peer review by experienced researchers in your field

- rapid publication on acceptance

- support for research data, including large and complex data types

- gold Open Access which fosters wider collaboration and increased citations

- maximum visibility for your research: over $100 \mathrm{M}$ website views per year

At BMC, research is always in progress.

Learn more biomedcentral.com/submissions 